\title{
The Archaeocyaths of Ifrane (Western Anti-Atlas-Morocco): Geological Value and Geotourism Development
}

\author{
Siham Albab ${ }^{1}$, Abdelkrim Ezaidi ${ }^{1}$, Mohamed Benssaou $^{1} \&$ Nezha Elkamali ${ }^{1}$ \\ ${ }^{1}$ Faculty of Science, University Ibn Zohr, Agadir, Morocco \\ Correspondence: Siham Albab, Faculty of Science, University Ibn Zohr, Agadir, Morocco. Tel: \\ 212-644-663-668. E-mail: siham_alba@live.fr
}

$\begin{aligned} & \text { Received: December 23, } 2013 \\ & \text { Accepted: January 8, } 2014 \quad \text { Online Published: February 20, } 2014 \\ & \text { doi:10.5539/jgg.v6n1p96 }\end{aligned}$ URL: http://dx.doi.org/10.5539/jgg.v6n1p96

\begin{abstract}
In the western part of the Anti Atlas, the Cambrian formations known since long (Nice, 1924; Bourcard, 1927; Bung \& Netlner, 1933), have been the subject of a very detailed stratigraphic approach. The sedimentological work affecting the lower Cambrian of the Western Anti Atlas is rare. It concerns mainly: a lithostratigraphic description and a summary interpretation of the environmental sedimentary formations.

Indeed, recent sedimentological data allowed a new lithostratigraphic division of the Lower Cambrian succession in three lithostratigraphic series. These, are characterized, each one, by a particular microbialitic builds ups, resulted, probably, from Lower Cambrian marine ecosystem variations. The first step, the stromatolitic series, represents a long period in which a large area of the Anti-Atlasic platform was occupied by peritidal cyanobacterial mats.

The second step, represented by the Thrombolites series, marks a global sea level rise (Thrombolites proliferation) relayed by a massive silico-clastic supply inputs. And the third stage of evolution during which the medium sufficiently deepened to allow the installation of the distal facies platform. The development of the Archaeocyaths seems to be one of the precursors of dendritic form acquired by certain microbial communities.

Dating Neoproterozoic, the Archaeocyaths of Ifrane, whose morphological diversity and the microbial communities associated with them, are a focus for the industry of ornamental rocks in Ifrane in the Moroccan western Anti-Atlas.

In this area, the structural diversity of the Archaeocyaths is very pronounced, which facilitates the systematic division and their use in stratigraphy. The perforations or pores vary in number, size and arrangement, those whose walls are stretched in the subdivision pore channels or tubes which may be linear, bent, or inclined in the case of thicker walls.

Indeed, the main objective of this work is to highlight the "Archaeocyathans mounds" as a geological heritage through the study of varied silico-clastic and carbonate predominate components facies. Regrettably, the surexploitation of the Archaeocyaths in the ornamental industry and mining activities may lead to their death in the absence of regulatory laws of their exploitation. Clues are offered to make the Archaeocyaths a geological site, a geological destination, thing that necessitate the conduct of a number of approaches, the mobilization of various networks of actors but also the establishment or adaptation of infrastructure, home or mediation.
\end{abstract}

Keywords: archaeocyathans mounds, neoproterozoic, geotourism, patrimonialisation, Western Anti-Atlas, Morocco

\section{Introduction}

Appearing at the onset of the Cambrian (Tommotian), the Archaeocyatheans mounds were already singular again by the end of the mid-Cambrian. They were most abundant during the Lower Cambrian, when they played an important biostratigraphic role (Enay, 1993). These are metazoans that originate directly, but independently from ancestors protozoa. These bioconstructions, can be described as reef structures (Benssaou, 2003; Hamoumi, 2004), by analogy with those described in the formations of Lower and Middle Cambrian trans-Antarctic mountains (Rees et al., 1989). They thrive under relatively turbulent hydrodynamic conditions (Wood, 1997) and preferably along the edges of slopes of offshore platforms in a hot climate. 
In the region of Bas Draa, the sedimentary succession of the lower Cambrian is thick approximately of $800 \mathrm{~m}$. However, in the absence of dating elements, the stratigraphic wedging of the series and formations remains unclear. From a lithological point of view, this succession can be subdivided into four units which are respectively from bottom to top: sandstone and base channelized, dolomitic limestones and Thrombolites, reefal Archaeocyatheans limestones and summit sandstone. The last two constitute the equivalent of the Archaeocyaths series.

In our study area, the morphological diversity of the Archaeocyaths and the associated microbial communities are responsible for their ornamental appearance very popular in the industry of ornamental rocks, which causes unfortunately, degradation of the geological heritage, and may lead to his death in a few years. Anyway, this particular view of the relationship between tourism development and resources conservation, making tourism development the best guarantee of the Archaeocyaths protection, is indicative of the position of the Archaeocyaths in the broader register of geosite to do the subject of protection. Thus the need for the establishment of a heritage process emerges.

Moreover, this protection aims:

The setting heritage of the Archaeocyathans mounds of the southern Morocco and the promotion of geotourism activities through the creation of a sustainable tourism product that will enjoyed a tourist, scientific and educational geographic perspective.

To guide stakeholders in tourism and local development towards new forms of heritage by focusing on three areas: resource protections, generate wealth, and promote the local potential.

\subsection{Geological and Paleographic Background}

Throughout the geological, biological and climatic events that have come and gone on Earth, those that characterize the Neoproterozoic (Superior-Cambrian) are among the most controversial. Multiple methods of investigation in Geology are operated in scattered ways and often lead to confusion, especially in the field of stratigraphy.

Indeed the boundary between the Neoproterozoic and the lower Cambrian is officially ratified in 1991. This limit, which is around $545 \mathrm{Ma}$ and which should, logically, separate an azo period (Proterozoic) and another fossil one (Phanerozoic), is far from the agreement of the researchers, responsible for the defining and the choice of the stratotype. The major events that characterize the Precambrian-Cambrian transition can be summarized in seven points:

- The breakup of a super-continent called "Super-Pangea" for some authors and Gondwana for others, by rifting process at the dawn of the Cambrian;

- The important climate change making succeed to tropical climates at equatorial of lower Cambrian to a glacial climate in terminal Proterozoic;

- The spectacular variation in isotopic record (C13) of the carbon element at the end of Vendian - early Cambrian;

- The biological diversity making succeed various biological stands which most have disappeared now;

- The biomineralization of animal skeletons for a better preservation of the fossils;

- The occurrence of an important episode of phosphatogenese in the early Cambrian;

- The total absence of vegetation on.

These geological climatic and biological variations are more or less recorded in the sedimentary succession in anti-Atlasic basin which was part of the Western platform of Gondwana in the Paleozoic. It should be noted in this connection that the gondwanan fragmentation is expressed at the level of the Anti-Atlas by a rifting, enhanced for the first time by the academic work, the study field carried out by (Besnaou, 2005) in the western part of the Anti-Atlas.

These studies extended on all the Anti-Atlas, are focused on the sedimentology. On the one side, they aim to contribute to the understanding of the impact of major sedimentation and sedimentary processes of the Cambrian variations, on the other side, the impact of the rifting on the nature of the deposits and the Organization of the facies sequence at the scale of the Anti-Atlas. 


\subsubsection{On a Global Scale}

This period represents the beginning of the Phanerozoic, around $545 \mathrm{Ma}$, which is interesting in more ways because: i) it separates azo period (Proterozoic) and another fossiliferous (Phanerozoic), ii) from a climate perspective, the Icehouse (glacial climate) of the Proterozoic type conditions are replaced by Greenhouse type conditions (tropical climate ) during the Lower Cambrian to the deposition of carbonates, iii) from a geodynamic and tectonic perspective, lower Cambrian is characterized by the fragmentation of the gondwanan continent and therefore the creation of marine platforms, iv) from an eustatic and oceanographic point of view, the beginning of the Cambrian period is marked by several phases of transgression to overwhelm new continental territories and therefore create new ecological niches, v) from an atmospheric perspective, there is an increase in the amount of oxygen in the atmosphere and ocean (Babcock, 2005) vi) from a point of view of environmental conditions, there is change caused by organic photosynthesis processes; (Vidal, 1998) and vii) from a biological point of view, it has logged an event of major order, which is the Cambrian radiation.

\subsubsection{At the Scale of the Anti-Atlas}

Between two periods of long duration dominated by detrital sedimentation, a short-lived leaves emerge clearly carbonate deposits.

In a particular physiographic context where the canopy is missing on continental areas, sedimentation will obviously be controlled by the action of tectonics in the hinterland. Lower Cambrian carbonates at the Anti-Atlas, resulting, consequently, of: i) the absence of detrital (relief leveled the hinterland), ii) a geodynamic context marked by a relative tectonic stability and iii) an active contribution of biomass in the sediment, in particular bioconstructive component. In its first stage, the bioconstruction is provided by simple non-calcified and therefore fragile toward the hydrodynamic conditions of the environment (stromatolites of Adoudou Training) of microbial organisms. In a second phase, the bioconstruction is reinforced by the emergence of a new generation of microbial communities called calcified (Thrombolites of Taliwine Formation or wine lees according to the nomenclature of Geyer and Landing, 1995). Calcified organic cyanobacteria tissue, offer in this regard, a significant resistance against the aggressions of sediment physical environmental factors. At the final stage of the bioconstruction, microbial communities are supported by the first metazoan organisms the bio (Archaeocyath). During this last stage of real buildings, there are erected reef and dynamic changes of the environment and other conditions are recorded in the diversity of facies observed in the field. It is through the study of this part of facies that the geological history of the Anti-Atlas is unveiled.

The Anti-Atlas is a mountain chain generally oriented NE - SW. It consists of a set of Proterozoic buttonhole surrounded by a Paleozoic cover. The base, deformed during the previous orogenic phases (Eburnean Pan and Hercynian) is, in fact, covered with angular unconformity by volcano-clastic and volcanic seated Precambrian III and the Lower Cambrian, which forms the bulk of the coverage. The unit is tectonically structured for most Hercynian phase in synclinal depressions wedged between the anticlinal buttonholes. These folds are affected by a few flaws overall directed (N160 and N70) with Anti-Atlas accident which is the major structural feature in the region. This accident, locally associated with Ophiolites, separates the Anti-Atlas domain NE and SW area. Geographically, the Anti-Atlas is divided into three areas: the eastern Anti-Atlas, the central Anti-Atlas and the western Anti-Atlas which is our study field.

In the western Anti-Atlas, where the axis of the lower Cambrian rift is localized (Pique et al., 1995), the Lower Cambrian series is thick and carbonate (Choubert, 1963; Benzyane et al., 1983). In this area, the Cambrian formations have long been known (Gentil, 1924; Bourcard, 1927; Bung \& Neltner, 1933), and have been the subject of a very detailed stratigraphic approach. Sedimentological works, however, are limited to a lithostratigraphic description and summary interpretation of training in terms of sedimentary environments in Tiout, Tazemourt and Amouslek (Geyer et al., 1995). In the Draa, the study by Buggische and Siegert (1989) contributed to the sedimentological characterization of terminals sandstone across the Anti-Atlas, the western High Atlas and the large deltaic complex d'Asrir in the Lower Draa.

\section{Field Work and Methodology}

\subsection{Study Area}

The area we propose to study is a side centered on two oases of western Anti Atlas Mountains, which are part of the region of Guelmim Es-Smara (South West of Morocco), a region that spans a total area in excess of 142. 000 $\mathrm{km}^{2}$ and occupies the $2 \mathrm{nd}$ place in the regions of the kingdom. Its territory can be divided into three major geographic areas: 


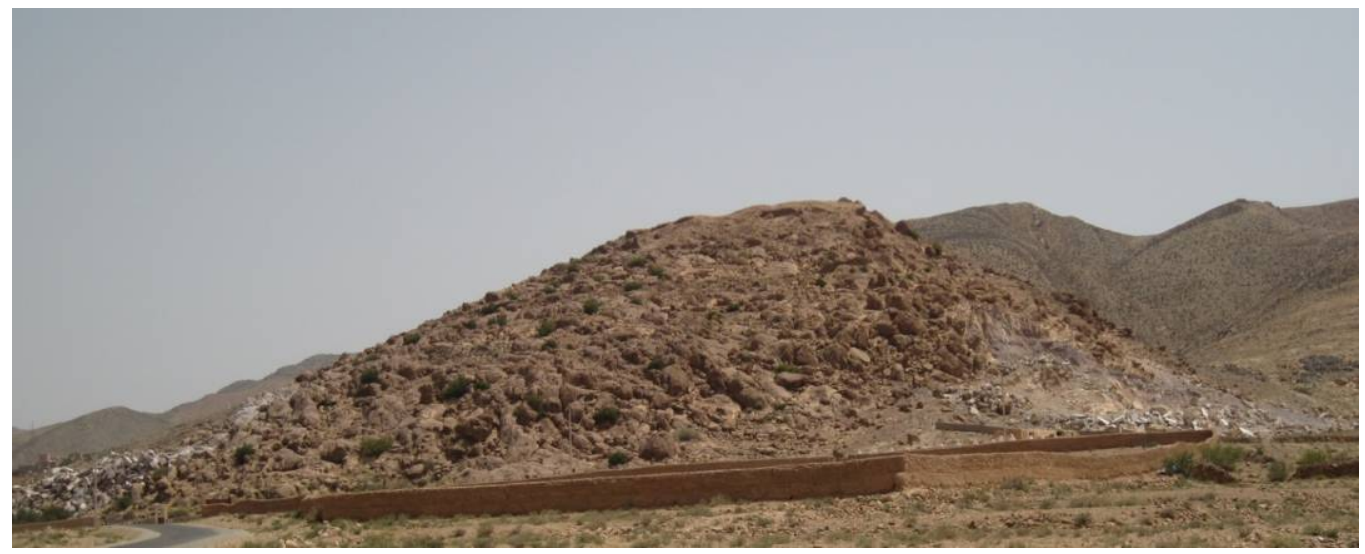

Figure 1. General view on the archaeocyathans mounds of Ifrane. Western Anti - Atlas (Morocco)

An area of mountains that forms the extension of the Anti-Atlas (zone sheltering the oasis of Taghjijt and Amtoudi). This mountain area is one of the major geological castles in the country. It is a mountainous, dry and arid area on its Saharian fallout from the Atlantic Ocean, starting from the birth of the Souss valley to the south east of Jebel Iguiguil and beyond in the direction of Keneg Tuerfa in Bani (halfway between Tata and Agadir Tissinnt). Directly backed the southern slopes of the Anti - Atlas and Taghjijt Amtoudi, two oasis between mountain and plain, are close to the desert oasis offering many natural resources: mountain forests, wetlands, and grasslands of altitude housing a particularly rich avifauna Bat (Tadarida Rhinopoma hardwickii and teniotis), Buzzard (Buteo buteo), European Bee-eater (Merops apiaster), residual mammalian fauna (Dorcas Gazelle Gazella dorcas, golden jackals (Canis aureus), Rats in wrong or MACROSCELIDS Rozet (Elephantulus roseus), a diversified flora where shrub vegetation is mainly composed of: Rhus tripartitum, Zyziphus lotus Euphorbia echinus, governing jubae, balsemifera, a unique geological heritage of its kind - all lending itself admirably to the development of ecotourism and geotourism diffuse. But this region is subject to pressures, both human and natural.

- A semi-desert area of plains that traverses heights at low altitude in the center.

- A desert area in the south.

It should be noted, finally, that this chain stands as a natural barrier and contributes to the softening of the arid climate by maintaining oceanic influences against dry seepage coming from the Sahara and cord large Hamada.

\subsection{Methodology}

This work is based on field data, bibliography and study in the laboratory (data compilation, preparation of thin sections, polished sections, image processing, etc.). The study on the collection of the field data to the outcrop, a first analysis is done on site. The study in laboratory, for morphology, petrography, the thicknesses, measurements, and the lateral and vertical path.

As a first step, the study of facies is mainly based on the definition and the characterization of the chosen facies, on the combination of several features: lithology, grain size, color, geometry and sedimentary structures. Facies can be likened to a simple bench that proliferates in relief the outcrop, a simple or composite strata interbanc and interbedded (Gubler et al., 1966). The classification and terminology of the alluvial detrital facies are based on the work of Miall (1978, 1988 and 1996). Facies study has for main objective the deduction of the hydrodynamic mechanisms and process of deposit they materialize from the lithology, sedimentary structures and other properties.

As a second step, facies association refers to a set of characteristic facies of a deposital environment. Several assemblages, lithologically different, can be reported to a common environment of deposition. For example the intertidal zone can be represented by an assemblage of silico clastic of tides, or purely carbonate stromatolites, or a blend of these two components. Constituent facies of an association can sometimes arrange in regressive or transgressive entities similar to the elementary sequences. It is an example of a minor fluvial channel where facies can move vertically from conglomerates to clays. 


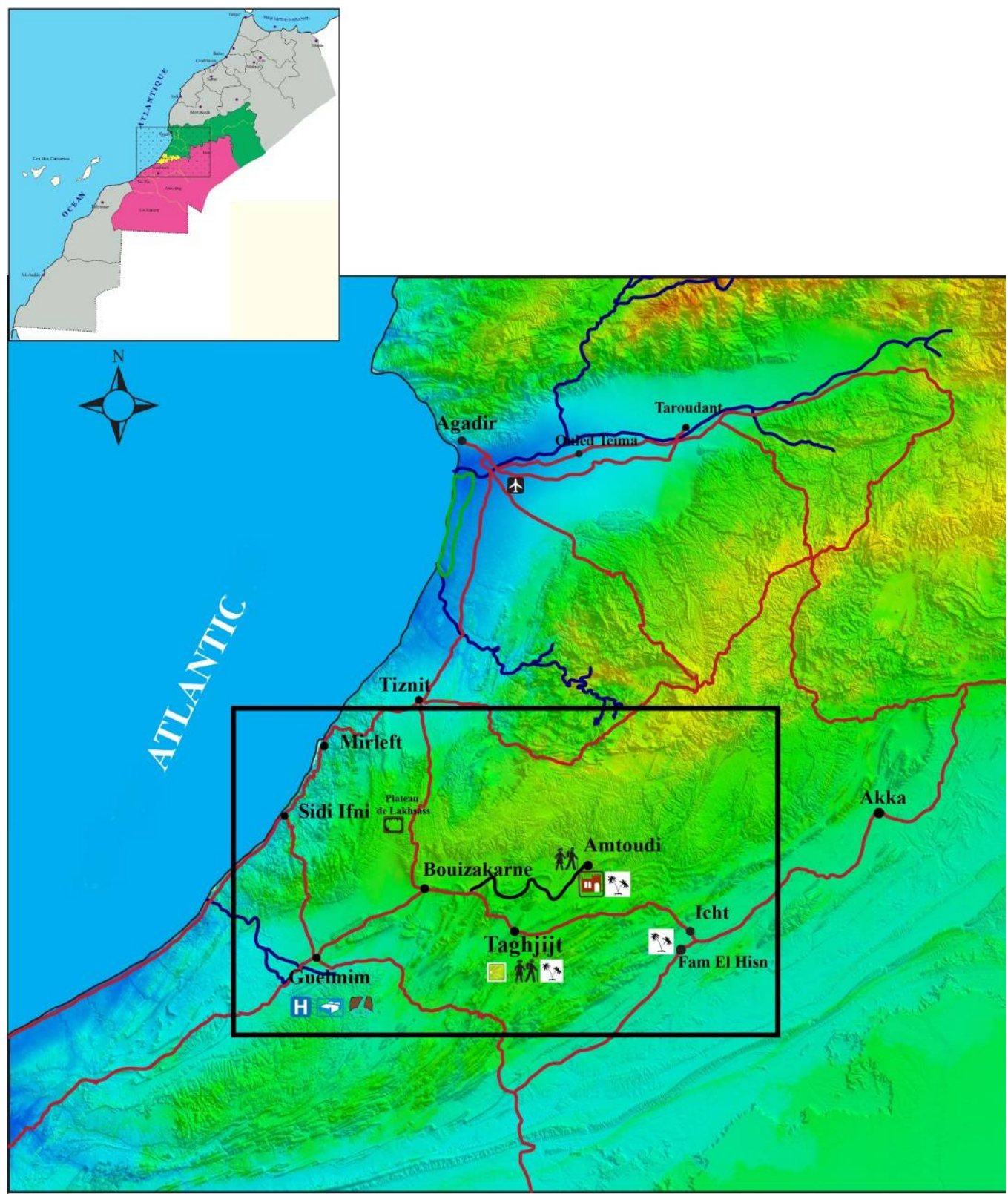

\section{study Area}

Legend

Main Roads

secondary Roads

Oueds
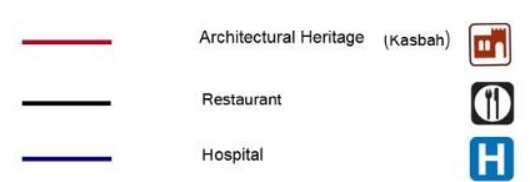

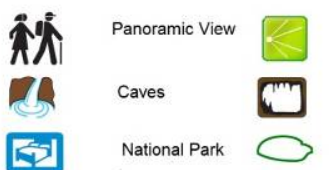

National Park $\bigcirc$

Figure 2. Map identifying our study area (Albab; Ezaidi, 2012)

\section{The Carbonate Facies of the Western Anti - Atlas: the Archaeocyaths}

In the Anti - Atlas, the major parts of the carbonate facies are of microbial origin. This results in the development of three varieties of bioconstructions (Stromatolites, Thrombolites Dendrolites reefs and Archaeocyaths). These microbial structures (formerly considered of algal origin) represent, according to Monty (1986), the oldest traces of biological systems organized for the optimal exploitation of the environment and its energy resources.

These structures produced by primitive substrata (Awramik \& Margilus; Walter, 1976; Monty, 1986), can resist 
various natural aggressive agents (radiation, drought, high or low temperatures, environmental instability, sediment influx etc.), allowing them to colonize a wide environmental range from hot springs to the most obscure seabed Monty (1986).

Because builder organisms correspond to benthic microbial communities (in particular cyanobacteria), organo-sedimentary structures are currently named microbolites (Riding, 1991) or microbialites (Schrieber, 1999; ARP et al., 1998, 1999; Glumac \& Walker, 1997; Neuweiler et al., 1997; Defarge \& Trichet, 1990). Morphological characterization of the structures within the Stromatolitic variety is largely derived from the classification of Logan et al. (1964).

In Ifrane, the Archaeocyaths series (Benssaou, 2004) is composed of alternating black siltstones and assize of grey limestone. In the silty-clayey intervals, limestone reefs at Archaeocyaths form clear massive floating in a clayey or silty dark matrix. These reefs are modeled in Bioherms, each measuring $100 \mathrm{~m}$ in thickness, so that their lateral extension can easily exceed one kilometer. The Bioherms of Ifrane are a part of the great Cambrian reef barrier of the Anti-Atlas, remarkably aligned NE - SW Vertical and lateral. Review shows that each Bioherm is formed by two separate limestone units from another by metric clay: The lower unit is generally rich in branched and solitary Archaeocyaths and grey colored limestone. The upper unit features similar to its lower counterpart, differs by its red color to purplish.

\subsection{Facies of the Lower Unit}

Main facies recognized within the limestones are: i) Grey Limestones of the colonial archaeocyaths and ii) gray lithoclastes limestone of clays and siltstones, iii) black limestones of solitary Archaeocyaths and iv) limestone varied diagenetic calcite.

\subsubsection{Reef Limestone in Solitary Archaeocyaths}

This facies is usually presented in the form of a black carbonate patina. The internal aspect of this facies shows, in addition to some solitary Archaeocyaths, speckles and micritiques dark stains irregularly distributed in a more or less clear micro-sparry background. Pluricentimetric spaces of white calcite frequently disrupt the consistency of the rock.

The dark colour of the micritiques particles reflects their richness in organic matter and, therefore, of intense microbial activity involved in their genesis. The Dendrolithes (in the terminology of Riding) erected adjacent mounds laterally bordering. The side passage of one mound to another, often leaves more or less large spaces where the calcite precipitates. Within a colony of Dendrolithes, the calcimicrobes are connected laterally to form colonies separated by varying in size and form voids. The white calcite which occupies the empty inter-monticules and inter-columnar materializes by clear zones within facies.

This type of reef facies or cyanobacteria are the main agencies, and Archaeocyaths play only a secondary role, matches facies framestone of Embry and Klovan (1971), it represents the stage in colonisation of the reef with a shy appearance of solitary Archaeocyaths. The number of individuals and species in the middle is very small because of the hydrodynamic conditions that probably still agitated despite stabilization of the bottom.

\subsubsection{Reef Facies in Colonial Archaeocyaths}

This facies is composed of a mass of greyish limestone that houses the dark spaces often irregular and regular in Archaeocyaths life position. Archaeocyaths form about $40 \%$ of the rock, so that the coloured rock part can be up to $50 \%$. The $10 \%$ that remain are often fashioned in form of patches of white calcite randomly distributed in the rock.

This facies shows two different phases of Genesis: a primary phase and another secondary:

The primary sedimentary phase is an hybrid bioconstruction where limestone is built both by microbial communities represented by the dark spots of limestone and Archaeocyaths:

Microbial communities here, are the dendritic cyanobacteria calcimicrobes, as evidenced by the dendritic irregular shape of the black portion of the rock. Cyanobacteria, in addition to their direct involvement in the mass construction of the reef, they live in colonies and their internal tissue is calcified, probably play a role similar to that of the zooxanthellae in the present coral reefs except that they do not live in symbiosis with Archaeocyaths. Cyanobacteria are, in this sense, capable of performing the phenomenon of photosynthesis and therefore reflect a medium covered by shallow water so that the light can invest it.

Archaeocyaths often appear in cross-sectional or longitudinal cut in the rock. The peripheral rings are often dyed black while the central part remains always clear because it's a vacuum filled by a limpid diagenetic calcite. The abundance of Archaeocyaths in this facies as sessile organisms (sentence deleted). 


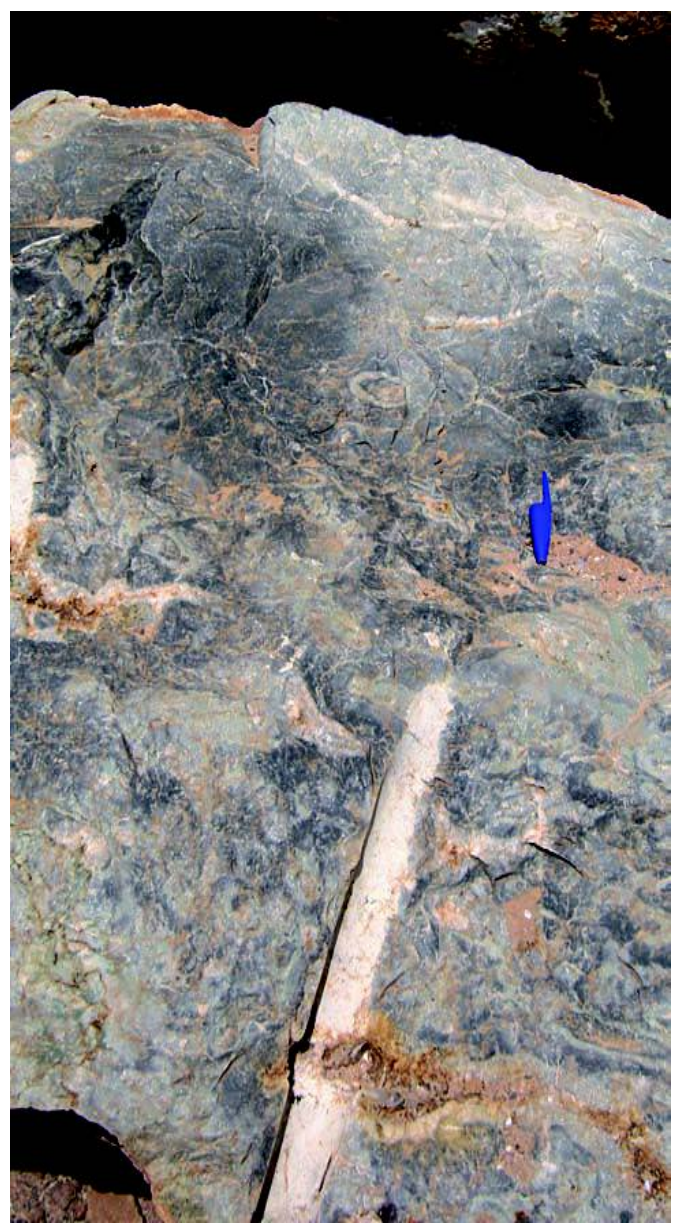

Figure 3. Grey reef limestone of solitary archaeocyaths

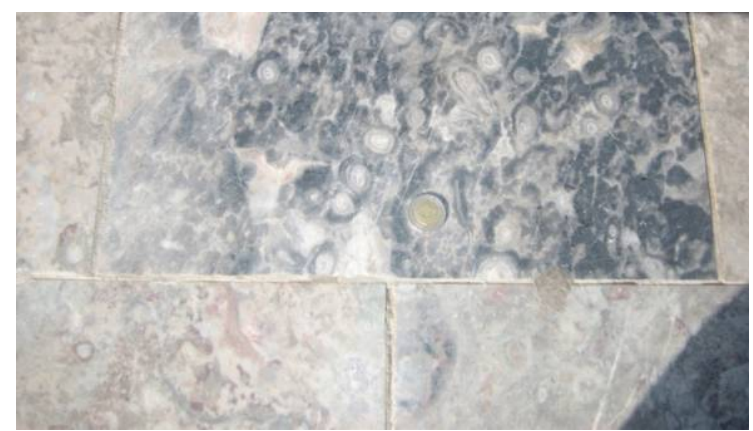

Figure 4. Example of reef facies in colonial archaeocyaths (grey limestone)

The secondary phase of the genesis of this facies is materialized by the white calcite resulting from early diagenetic precipitation in voids and pores not occupied by the terms. In the case of the Archeocyaths-bearing limestones, the empty portion is represented by the intercolonial spaces (between columns and Archaeocyaths calcimicrobes for example) and Archaeocyaths, even those which are primary originally voids occupied by live organic fabrics, they eventually disappear after death and leaves voids where the white calcite may precipitate. In relation to hydrodynamic conditions, this facies represents a late stage in the evolution of reef construction. It's probably the stage of diversification where the reef develops both vertically than laterally. The reef has now reached the area of action of the swell, and bioclastic debris began to appear and spread around the built mass. The diversification of species and the number of individuals becomes very important. In addition, this facies demonstrates the degree of strength of the reef structure to better withstand the wave energy. Such resistance is ensured through the calcite which precipitates inside the microbial organic tissue. In addition, Archaeocyaths in 
limestone correspond to bafflestone type of Enbry and Klovan facies. Their calcareous skeleton as well as the abundance of individuals contributes to the solidity of the reef structure. Diagenetic filling of gaps by early calcite makes it even harder and more resistant facies.

\subsubsection{Limestone Stromatactis or Fenestrea}

This rare and solitary Archaeocyaths facies is essentially characterized by the presence of a centimeter decimeter white calcite and irregularly shaped spaces.

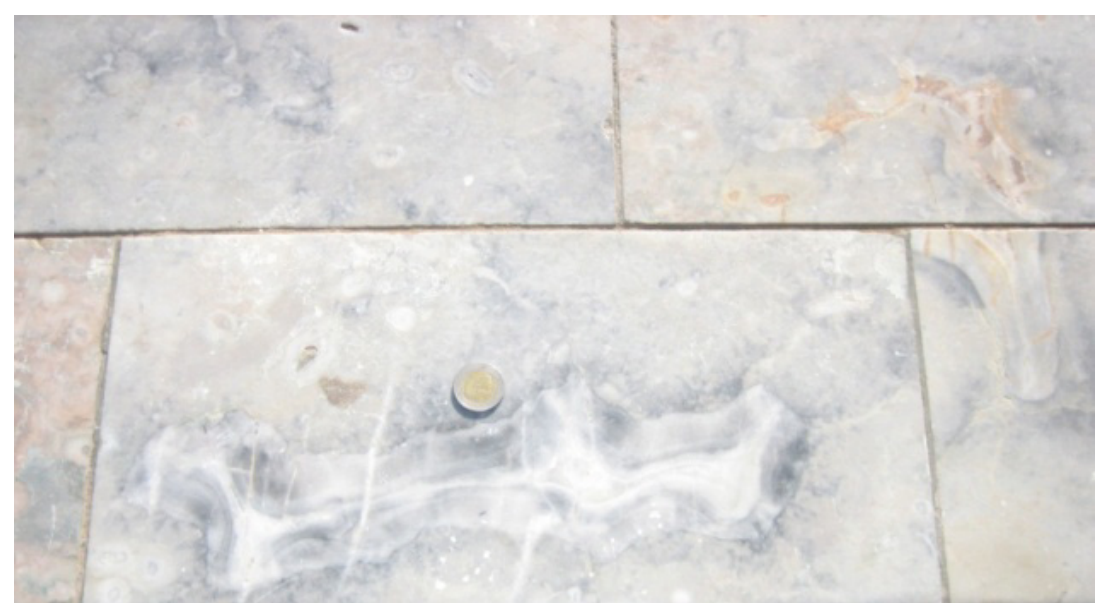

Figure 5. Stromatactis grey reef limestone

This facies mainly built by the calcimicrobes shows relatively unfavorable to the development of the Archaeocyaths. The emersion of the reef by vertical growth facilitates its subaerial karstification. Thus shaped cavities are filled by concentric calcite of diagenetic origin in the absence of a detrital influence. These calcite-filled cavities are called "Stromatactis" and characterize a reef environment subjected to the action of the waves. The Stromatactis as well as the scarcity of fragile bodies against the waves like Archaeocyaths make this texture the equivalent of bindstone facies of Embry and Klovan that illustrates the final stage of the development of the reef or the stage of domination.

\subsubsection{Grey Limestone in Lithoclastes of Clays and Siltstones}

Within the reef limestones, often appear irregular clasts of greenish clay or a purple Siltstone of varying size. These clasts are sometimes separated from the limestones that harbor by a centimetric waveband of structured white calcite laminae in millimeter.

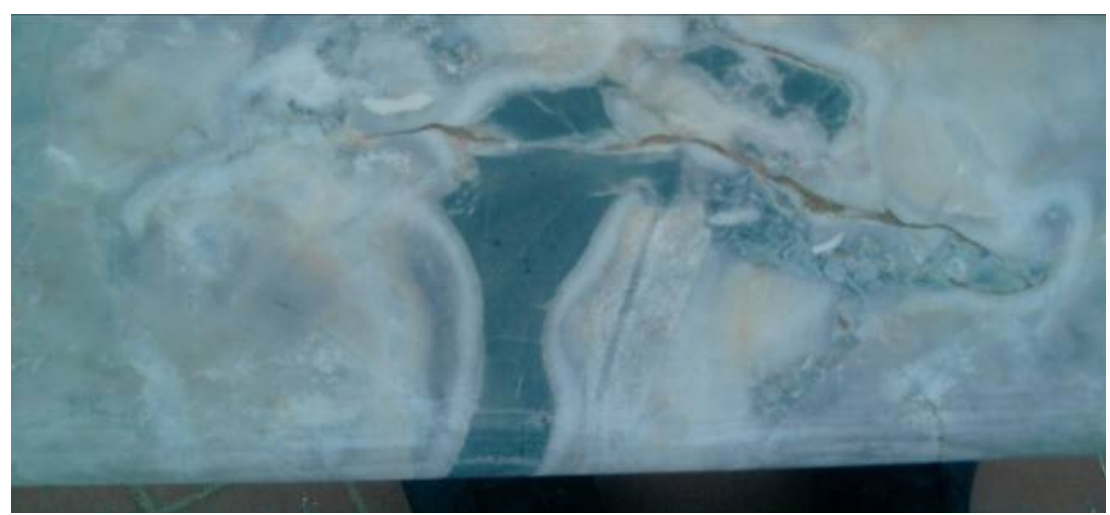

Figure 6. Grey limestone of solitary archaeocyaths and lithoclastes of green clay

Detrital clasts represent the beginning of the establishment of a detrital episode in the middle. Indeed during the stage of emersion of the reef, its uppermost surface is subject to the phenomena of karstification. These 
structures of dissolution have a diameter that can reach several tens of centimetres at the top and which becomes narrower while the cracking penetrates into the rock, they eventually become irregular cracks of centimetres thick in millimetres and sometimes bifurcated.

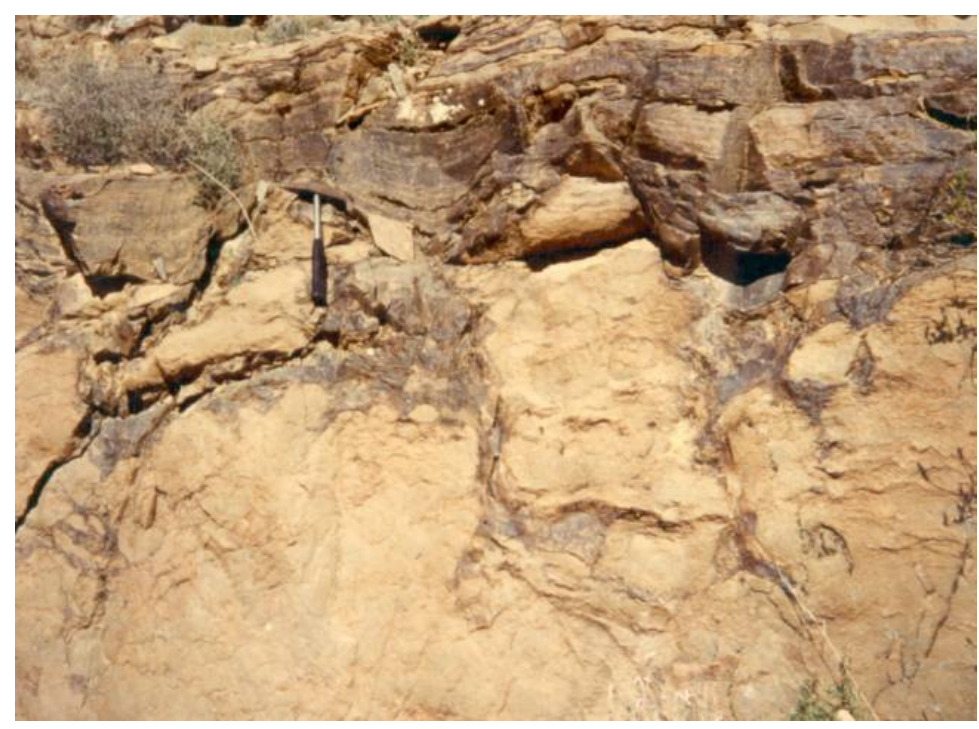

Figure 7. Reef limestone of the colonial Archaeocyaths and lithoclastes of green clay

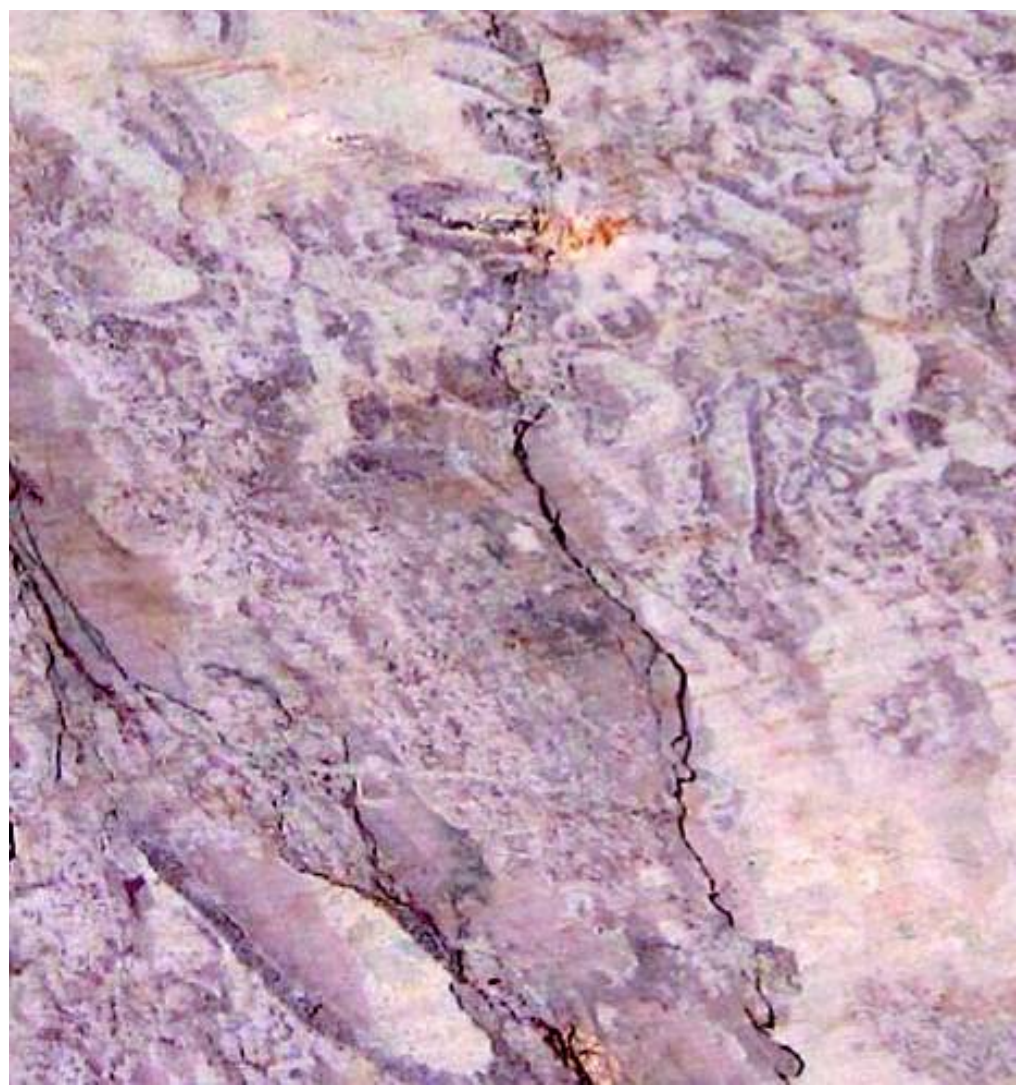

Figure 8. Example of reef facies in colonial archaeocyaths (reddish limestone)

Where these internal gutters are inaccessible at the detritism and not clogged by diagenetic calcite, bioconstruct facies of microbial origin arise. The result is a juxtaposition of reef facies (different origins). 


\subsection{Facies of the Upper Unit}

\subsubsection{Purple to Reddish Limestone of the Archaeocyaths Reef}

This facies is different from the previous only by its red or purplish color. The limestone mass is built by Archaeocyaths which are bathed in a reddish limestone bottom strewn with uneven spaces of clear calcite. Archaeocyaths themselves show a red peripheral stain skeleton formed in the central part, sometimes a white calcite and sometimes by a reddish or purple phase. The ornamental specificity in terms of the color of this facies, is probably related to the abundance, at the time of the bioconstruction, from the impact of contemporary volcanic clouds. It's probably some sort of Red Sea whose color is dictated by the sediments of volcanic origin of the same color.

Despite their bioconstructed origin, these Archaeocyaths limestones are mostly impure limestones. According to Alvaro and Debrenne (2010) some limestone facies contain up to $40 \%$ insoluble residue by acid. These residues are volcanic feldspathes of clasts of glass splinters (65\% the insoluble residue), and other auto-genetic and detrital minerals, like quartz, apatite, pyrite and clay minerals.

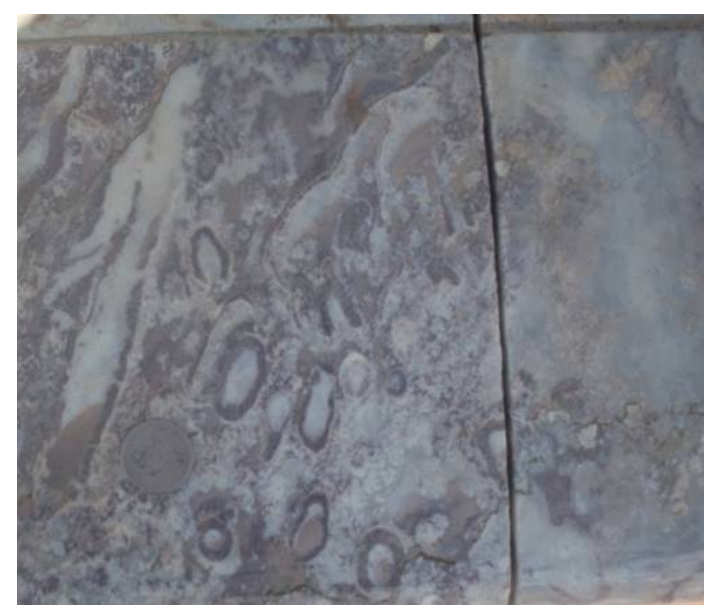

Figure 9. Colonial Archaeocyaths in longitudinal and transversal sections

Microbial communities, after the manner of Stromatolites, are clearly able to agglutinate a fraction of detrital sediments as the volcano-sedimentary reddish particles and acquire a red or purplish ones. Archaeocyaths, on their part, are not filter feeders such as current corals, but suspension feeders that capture food scattered in the water flowing through the pores of their wall. Purplish detrital particles present in the water, at the time of volcanic eruptions, are sometimes trapped inside the organic fabric of Archaeocyaths and resultant coloring of their peripheral rings. The central part of the Archaeocyaths remains empty as long as the movement of water through pores in the wall ensures emptying and would later be filled by diagenetic white calcite. Indeed, the detrital phase of volcanic origin becomes abundant and evacuation is no longer ensured, the central vacuum is clogged by reddish detritus and led to the asphyxiation of Archaeocyaths.

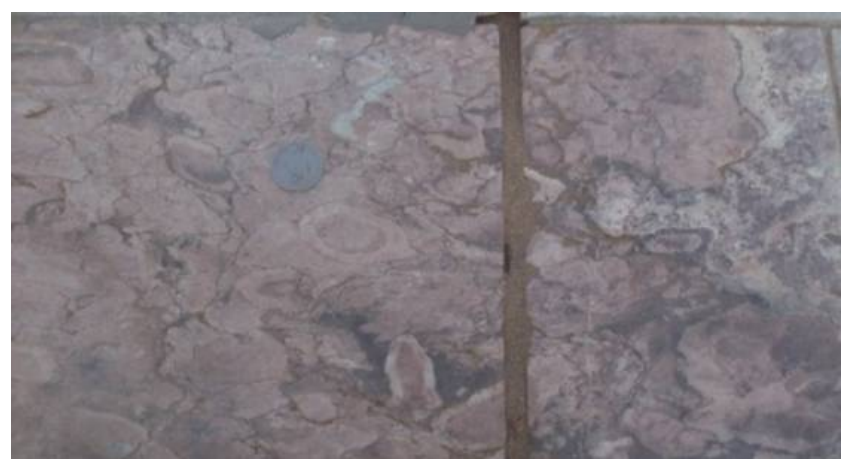

Figure 10. Archaeocyaths in cross-section showing the central part filled by detrital sediment 
Clear calcite that appears within the microbial fabric is in this case, are the product of a late diagenetic precipitation at the time where the detrital phase disappears completely from the Middle, following the cessation of volcanic activity. Calcite replaces part of the organic matter of the cyanobacteria late destroyed. In all cases, the dominance of the purple and reddish color announces the decline of the biocontruction and the introduction of detrital sedimentation.

Table1. The facies associations

\begin{tabular}{llll}
\hline $\begin{array}{l}\text { Facies } \\
\text { associations }\end{array}$ & $\begin{array}{l}\text { Constituent } \\
\text { facies }\end{array}$ & $\begin{array}{l}\text { Facies organization and } \\
\text { other features }\end{array}$ & $\begin{array}{l}\text { Sedimentary processes and } \\
\text { environments of deposition }\end{array}$ \\
\hline AF d1 & $\begin{array}{l}\text { Bioconstructions } \\
\text { reef (facies C } \\
\text { bioh) }\end{array}$ & $\begin{array}{l}\text { Lenses from 2 to } 30 \text { meters of } \\
\text { thickness and extent regional } \\
\text { lateral }\end{array}$ & $\begin{array}{l}\text { Constructed by wood, Archaeocyaths and } \\
\text { the calcimicrobes proliferate under } \\
\text { relatively turbulent hydrodynamic } \\
\text { conditions and preferably along the edges } \\
\text { of slopes of marine platform. }\end{array}$ \\
AF d2 & $\begin{array}{l}\text { Bioconstructions } \\
\text { reef (facies C } \\
\text { biost) }\end{array}$ & $\begin{array}{l}\text { Limestone beds with black or } \\
\text { whitish thick patina (one to } \\
\text { two meters and lateral } \\
\text { extension regional facies } \\
\text { Cbiost). }\end{array}$ & $\begin{array}{l}\text { Constructed in large part by the } \\
\text { calcimicrobes, Archaeocyaths play only a } \\
\text { secondary role. They proliferate in a calm } \\
\text { environment of a flat distal form. }\end{array}$ \\
\hline
\end{tabular}

The different facies associations that make up this series fit laterally along a tree-lined distal side platform with a low slope angle. In this platform, which can be qualified as ramp, deposits show a progressive side passage from the proximal part to relatively coarse sediment subjected to the swells and tides action.

In this configuration, discontinuation or reduction of the siliciclastic arrivals allows the development of carbonates. Granular and biostromal reef limestone occupy the middle of the ramp, while the reefs of high energy settled on the edges of the slope. The influx of terrigenous siliciclastic deposits causes a complete fading of carbonates and promotes the extension of siliciclastic deposits to the field of offshore (distal ramp) in the form of thin interbeds. Indeed when a deltaic system is taking place at the level of the littoral during maximum flood, the greatest mass of fluvial deposits are deposited in the coastal plain and therefore, front deltaic prograde slowly and only fine deposits are transported to offshore, by the action of waves and storms (Einsel, 1992). This lateral facies zonation characterized a deltaic system totally or partially dominated by swell (Allen \& Mercier, 1987; Bhattacharaya \& Walker, 1991; Orton \& Reading, 1993). At the time of the fall of the sea levels, on the other hand, the siliciclastic terrigenous facies prograde quickly in the platform as deltas where the distal part can be redrafted by the storms. During this fall of the sea level, deltaic sediments, altered or not, undergo more or less significant erosion. The passage of the siliciclastic-carbonate sedimentation is brutal at the level of the littoral where the river intake is important while it is progressive distal platform where the terrigenous contribution is reduced. In this case, this passage is expressed by the intercalation of thin levels and lenses carbonated within the rated rhythmites in offshore area

\section{Discussion}

Bioherms in the Western Anti-Atlas qualify reef constructions by analogy with those described in the lower and middle of the trans-antarctiques Mountains in the Cambrian formations (Rees et al., 1989). They proliferate under hydrodynamic conditions relatively choppy (Wood, 1997) and preferably along the slopes of plate margins marine form. The different facies associations that constitute the reef of Ifrane of the Anti-Atlas fit vertically along a tree-lined platform side distal with a low angle slope.

The vertical arrangement of the facies shows that solitary Archaeocyaths facies represents the stage of colonization where microbial communities are the main bioconstructor. The two varieties of colonial Archaeocyaths limestones represent the stage of diversification and bears witness to a vertical growth of the reef. In addition, the red variety is a contemporary meter volcanic sedimentation activity. Stromatactis facies represents the stage of domination and brand high agitation conditions that disrupt the development of Archaeocyaths. Clay clast limestone facies shows, meanwhile, of a solid contribution in detrital sediments that filled Karst surface irregularities of the reef now in stage of domination. These fine-grained sediments can penetrate deep into the limestone mass bioconstructed. Identified facies indicate that the Archaeocyaths 
biocontructions of the Anti-Atlas are real reefs with a frame that resists the action of the wave.

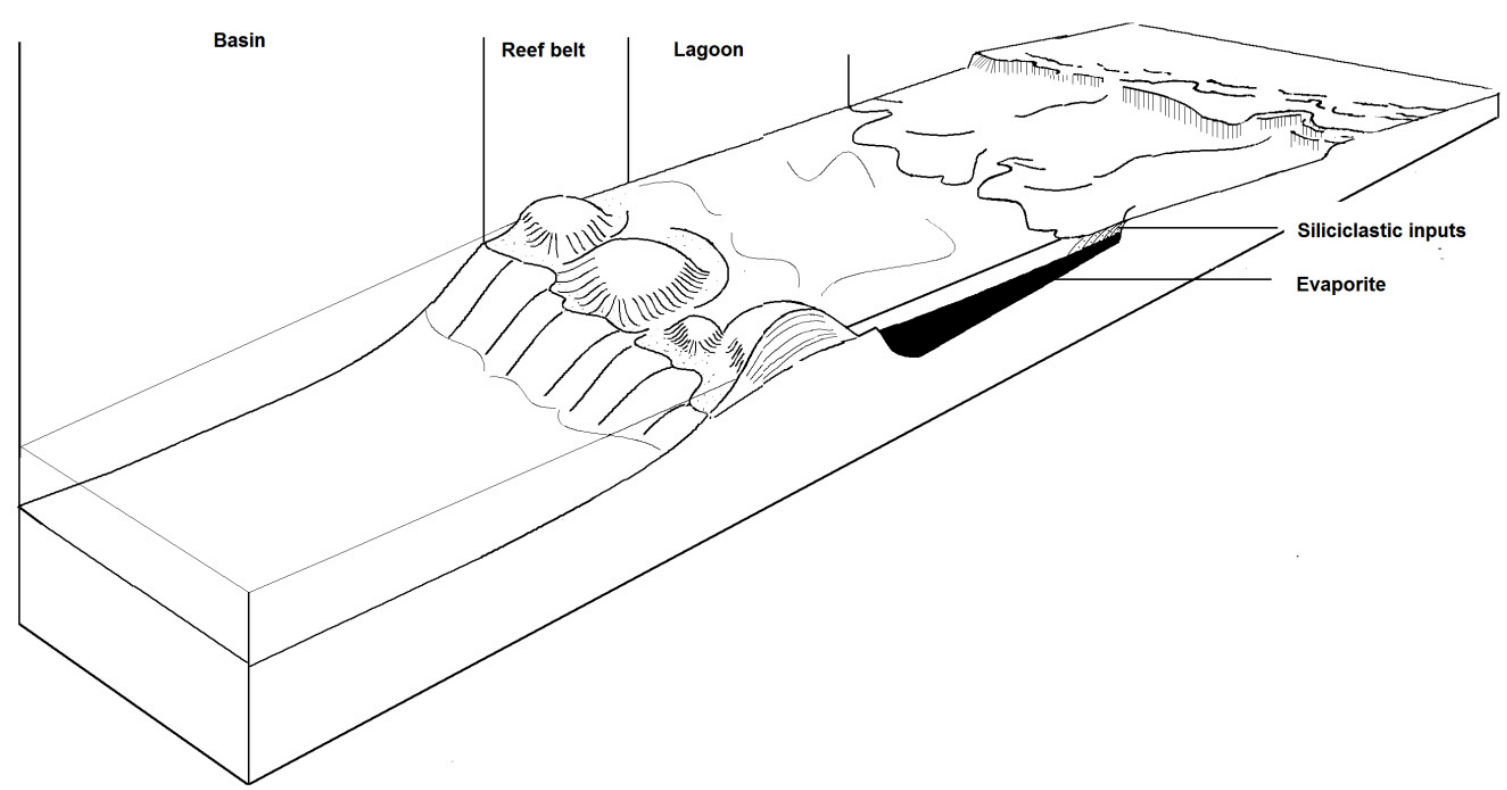

Figure 11. Reconstitution of the paleoenvironments and bathymetric distribution of the microbialitic facies of the Lower Cambrian in Bas Draa

Within this Paleogeographic configuration, discontinuation or reduction of the siliciclastic arrivals allows the development of carbonates. The reefal limestones especially the biostromes, occupy the middle zone, while the reefs of high energy as those of Ifrane of the Anti-Atlas settled on the edges of the slope. The influx of terrigenous siliciclastic deposits by the dynamics of storms or the redistribution of the contemporary volcano-clastic product causes more or less full shading of carbonates and transforms the Red Sea environment in the case of volcanic influence.

As a deduction, Archaeocyaths represent a geological wealth of its kind in the South of the Morocco and who suffer unfortunately from a surexploitation who can take to their extinction because of the intensive mining extraction activity. Indeed, in the absence of a regulatory act, the exploitation of Archaeocyaths in the ornamentation industry of the facades, footpaths in cities, the fate of these rocks still vulnerable. The lack of efforts on the conservation of the geological heritage is due to the widespread idea that rocks and landscapes do not require special handling and special protection because of their robustness (Komoo, 2003). Although the idea applies to some geological objects, most sites are fragile. Fossil sites are typical examples of this case. Indeed, the threats facing these sites include (Lee, 2000): exploitation of mines and quarries, as well as natural risks.

In our study area, the Archaeocyaths formations have experienced an intense natural and anthropogenic degradation:

Four large formations appear (Issafene formation, the formation of Amouslek, the formation of Tiout and the formation of Ifrane of the Anti-Atlas). On the one side, all these potential geosites, have suffered from mining operation with different degrees. The first three sites are facing a moderate exploitation, unfortunately, the formation of Ifrane is suffering from a real overexploitation that may lead to it's loss.

On the other side, natural degradations are manifested in the form of cracks in rocks, erosion, water infiltration, through the destructive action of the fluvial, wind erosion and thermal variations (temperature difference between the day and night). Admittedly, this type of degradation remains tiny in front of the anthropogenic degradation specifically those related to mining activity that will soon make these spaces one of the forgotten ordinary places.

Some sites have unfortunately served as quarries of stones, used by local populations, in the construction of houses, and by nomadic and semi-nomadic populations in the realization of the shelters during their transhumance.

Destruction of such witnesses of the history of Earth and life is irreparable, because these witnesses can no 
longer be restored or found elsewhere. They, therefore, need prior protection from their degradation or destruction, the type of protection and maintenance widely depending on their development and their use. These sites are to be kept for posterity. They are to protect actions that are detrimental to their content, their structure, their form or their future natural evolution. The geosites as "protected areas" must be selected during the planning process by relying on the inventory of these sites.

Indeed, the Archaeocyaths Geotourism requires the conduct of a number of steps, passing first by the resource inventory, a phase of identification of properties and values of the geosite, through grids that lead to the assessment of the qualifications of the geosites. Unfortunately, in Morocco, the sites are not inventoried by the State but rather by researchers and academics that accumulate inventory after inventory in their drawers.

After the inventory phase, comes the phase of the protection of the resource. Grids for evaluating the sites, contain criteria concerning the vulnerability of the site, thus, local actors, may give priority to the more vulnerable than other sites.

All this may not be possible without the mobilization of the networks of actors at different levels, if the scientists and institutional actors are incountournable in a first phase of creating a Geotourism product, other networks shall be solicited. Also, from a perspective of tourist development of the geoHeritages, four types of actors can intervene: my scientists, cultural mediators, people, and communities at different scales.

\section{References}

Albab, S., \& Ezaidi, A. (2012). Map identifying the study area.

Arp, G., Hofmann, J., \& Reitner, J. (1998). Microbial fabric formation in spring mounds (“microbialites") of alkaline salt lakes in the Badain Jaran sand sea, PR China. Palaios, 13(6), 581-592. http://dx.doi.org/10.2307/3515349

Awramik, S., Margulis, L., \& Barghoon, E. S. (1976). Evolutionary processes in the formation of stromatolites. In M. R. Walter (Ed.), Stromatolites (pp. 149-162).

Benssaou, M. (2001). L'Anti-Atlas occidental du Maroc: étude sédimentologique et reconstitutions paléogéographiques au Cambrien inférieur. Journal of African Earth Sciences, 32, 351-372. http://dx.doi.org/10.1016/S0899-5362(01)90102-2

Benssaou, M., \& Hamoumi, N. (2003). Le graben de l'Anti-Atlas occidental (Maroc): contrôle tectonique de la paléogéographie et des séquences au Cambrien inférieur. Comptes Rendus Géoscience, 335(3), 297-305. http://dx.doi.org/10.1016/S1631-0713(03)00033-6

Benziane, F., Prost, A., \& Yazidi, A. (1983). Le passage du Précambrien au Cambrien précoce volcanique et sédimentaire de l'Anti-Atlas oriental; comparaison avec l'Anti-Atlas occidental. Bulletin de la Societé géologique Français, 4, 549-556.

Bourcard, J. (1927). Découverte du Cambrien à archéocyathus dans l'Anti-Atlas marocain. C. R. Som. Geol. Fr., $10-11$.

Buggisch, W., Siegert, R. (1988). Paleogeography and faciès of "Grès terminaux" (uppermost Lower Cambrian, Anti-Atlas/Morocco). In V. H. Jacobshagen (Ed.), The Atlas system of Morocco. Studies on its Geodynamic Evolution. Lecture note in EarthSciences 15107-121, Berlin, Heidelberg, New York, London, Paris, Tokyo (Springer Verlag).

Choubert, G. (1964). Histoire géologique du Précambrien de l'Anti-Atlas (Vol. 162). Éditions du Service géologique du Maroc.

Debrenne, F., Debrenne, M., Faure-Muret, A. (1990). Faune d'Archéocyathes de l'Anti-Atlas occidental (bordures Nord et Sud) et du Haut Atlas occidental. Cambrien inférieur, Maroc. Géologie Méditerranéenne, Tome XVII, 3-4, 177-211.

Enay, R. (1993). Paleontology of invertebrates:diploblastic metazoans porifera and archaeocyatheans (pp. 33-51). Berlin.

Gentil, L. (1924). Atravers l'Anti-Atlas et le Jbel Bani (Sud marocain). Bull. Comité Afr. Fr., Paris, 196-226.

Geyer, G., \& Landing, E. (1995). The Cambrian of the Moroccan Atlas regions. Morocco, 95, 7-46.

Glumac, B., \& Walker, K. R. (1997). Selective dolomitization of Cambrian microbial carbonate deposits: A key to mechanisms and environments of origin. Palaios, 98-110. http://dx.doi.org/10.2307/3515300

Komoo, I. (2003). Conservation geology: protecting hidden treasures of Malaysia. Institute for Environment and 
Development, Universiti Kebangsaan Malaysia.

Lee, C. P. (2000). Conservation of fossils sites in Malaysia. In I. Komoo \& M. S. Leman (Eds.), Geological Heritage of Malaysia, Resource development for conservation and Nature Tourism, LESTARI UKM Publication, Bangi.

Logan, B. W., Hoffman, P., \& Gebellin, C. D. (1974). Algal mats, cryptagal fabrics and structures, hamelin pool, western Australia. The americain assoc. of petro. Geol. Memoire, 22, 141-194.

Miall, A. D. (1978). Lithofacies types and vertical profile models braided river deposits: a summary. In A. D. Mial (Ed.), Fluvial sedimentology, Can. Soc. Petrolum Geologists, Mem. 5, 597-604.

Miall, A. D. (1988). Architectural elements and bounding surfaces in fluvial deposits: anatomy of the Kayenta formation (LowerJurassic), Southwest Colorado. Sedimentary Geol., 55, 233-262. http://dx.doi.org/10.1016/0037-0738(88)90133-9

Monty, C. L. V. (1986). Interactions événements géologiques-Stromatolites. Bull. Cent. Rech. Explor. Prod. Elf Aquitaine, 10, 537-553.

Neuweiler, F., Reitner, J., \& Monty, C. (1997). Biosedimentology of microbial buildups. Facies, 36, 195-284. http://dx.doi.org/10.1007/BF02536885

Piqué, A., Dahmani, M., Jeannette, D., \& Bahi, L. (1987). Permanence of structural lines in Morocco from Precambrian to present. Journal of African Earth Sciences, 6(3), 247-256.

Rees, M. N., Pratt, B. R., \& Rowell, A. J. (1989). Early Cambrian reefs, reef complexes, and associated lithofacies of the Shackleton Limestone, Transantarctic Mountains. Sedimentology, 36(2), 341-361. http://dx.doi.org/10.1111/j.1365-3091.1989.tb00611.x

Riding, R. (1991). Cambrian calcareous cyanobacteria and algae. In Riding (Ed.), Calcareous algae and stromatolites (pp. 21-51). Berlin: Springer-Verlag.

Schieber, J. (1999). Microbial mats in terrigenous clastics; the challenge of identification in the rock record. Palaios, 14(1), 3-12. http://dx.doi.org/10.2307/3515357

Wood, R. (1997). The early Cambrian reef ecosystem. Proc. 8th Int. Coral Reef Sym, 2, 1631-1636.

\section{Copyrights}

Copyright for this article is retained by the author(s), with first publication rights granted to the journal.

This is an open-access article distributed under the terms and conditions of the Creative Commons Attribution license (http://creativecommons.org/licenses/by/3.0/). 